\title{
Divided Development: Post-War Ideas on River Utilization and their Influence on the Development of the Danube
}

Citation for published version (APA):

Lagendijk, V. C. (2015). Divided Development: Post-War Ideas on River Utilization and their Influence on the Development of the Danube. The International History Review, 37(1), 80-98.

https://doi.org/10.1080/07075332.2013.859165

Document status and date:

Published: 01/01/2015

DOI:

10.1080/07075332.2013.859165

Document Version:

Publisher's PDF, also known as Version of record

Document license:

Taverne

Please check the document version of this publication:

- A submitted manuscript is the version of the article upon submission and before peer-review. There can be important differences between the submitted version and the official published version of record.

People interested in the research are advised to contact the author for the final version of the publication, or visit the DOI to the publisher's website.

- The final author version and the galley proof are versions of the publication after peer review.

- The final published version features the final layout of the paper including the volume, issue and page numbers.

Link to publication

\footnotetext{
General rights rights.

- You may freely distribute the URL identifying the publication in the public portal. please follow below link for the End User Agreement:

www.umlib.nl/taverne-license

Take down policy

If you believe that this document breaches copyright please contact us at:

repository@maastrichtuniversity.nl

providing details and we will investigate your claim.
}

Copyright and moral rights for the publications made accessible in the public portal are retained by the authors and/or other copyright owners and it is a condition of accessing publications that users recognise and abide by the legal requirements associated with these

- Users may download and print one copy of any publication from the public portal for the purpose of private study or research.

- You may not further distribute the material or use it for any profit-making activity or commercial gain

If the publication is distributed under the terms of Article $25 \mathrm{fa}$ of the Dutch Copyright Act, indicated by the "Taverne" license above, 


\section{The International History Review}

\section{Divided Development: Post-War Ideas on River Utilisation and their Influence on the Development of the Danube}

\section{Vincent Lagendijk}

To cite this article: Vincent Lagendijk (2015) Divided Development: Post-War Ideas on River Utilisation and their Influence on the Development of the Danube, The International History Review, 37:1, 80-98, DOI: 10.1080/07075332.2013.859165

To link to this article: https://doi.org/10.1080/07075332.2013.859165

曲 Published online: 16 Jan 2014.

Submit your article to this journal

Џ Article views: 281

Q View related articles $₫$

View Crossmark data ¿

Citing articles: 5 View citing articles $\sqsubset$ 


\title{
Divided Development: Post-War Ideas on River Utilisation and their Influence on the Development of the Danube
}

\author{
Vincent Lagendijk*
}

\begin{abstract}
In the 1950s the United States feared that the Soviet Union would overtake their leading position in river development. The Tennessee Valley Authority had become a household name across the globe, but now the Soviets, too, began to share their expertise in this field. This article examines how Soviet experiences were applied on the river Danube. It hence discusses the cold-war discourse of modernisation, exemplified by river development, from both the capitalist and Communist perspective. Particular attention is paid to the institutional context of this transfer, the Council of Mutual Economic Assistance, and the attempts of the United Nations Economic Commission for Europe to play a role in this process.
\end{abstract}

Keywords: river development; East-West relations; CMEA; international organisations

A 1957 US Senate Committee report raised grave concerns: 'The Soviets are climaxing this continuing endeavour in the proclaimed belief that results will assure these Communist nations surpass the United States in any competition existing in this major economic field.' This field was river development: the practice of putting running water to work for industry, agriculture, and society as a whole. 'The Communist countries' realistic effort and emphasis in executing these irrigation, hydroelectric, flood-control, and water-transport functions', the Senate report continued, 'are more powerfully and longer sustained and exceed in volume and sacrifice involved all their missile and satellite performances [...]'. ${ }^{2}$

This citation, and the report as a whole, acknowledges historian Odd Arne Westad's point that during the cold war the United States regarded Soviet Communism as an 'alternative modernity', and therewith a potential rival of 'Americanism'. ${ }^{3}$ His colleague Michael Latham defines 'modernisation' as both an intellectual theory and a political practice. ${ }^{4}$ Indeed, the 'West' did not monopolise development ideas and assistance. One observer in 1965 noted that '[i]t is not only the West, of course, which is "in the market" as concerns foreign aid', as the Soviet Union had struck technicalassistance agreements with over thirty developing nations. ${ }^{5}$

From the 1950s onwards, much of the Soviet Union's foreign assistance aimed at industrial development, including transport and communications, as well as hydroelectric power projects. The Soviets indeed built - or at least claimed to - at

*Email: vincent.lagendijk@maastrichtuniversity.nl. An earlier version of this paper was presented at the 2011 annual meeting of the Society for the History of Technology in Cleveland, Ohio. The author profited from comments made by Sara Pritchard and several invaluable insights of Jíra Janác, as well as the highly useful comments of three anonymous reviewers. 
sizes that made Western hydro plants, for example, look like 'watermills from the Middle Age'. ${ }^{6}$

Were the Senate report's fears really justified? Was the Soviet Union an active promoter of its own 'style' of river-basin development? How did this compare and contrast to the US way of river (re-)engineering, in particular the Tennessee Valley Authority (TVA)? This article will answer these questions with the development of the Danube as case study. It thus examines the cold-war discourse and praxis of modernisation, and in particular river development, as seen through both a capitalist (or, 'democratic') and Communist lens. This is a novel approach. Previous studies have identified the cold-war relevance of river development and its discourse as a potent instrument of showing superpower capabilities. They did so primarily from a US perspective. From that point of view, river development was seen as 'weapon' against underdevelopment, thereby taking away potential fertile ground for the proliferation of Communism. ${ }^{7}$ This article integrates the Socialist perspective into the equation.

The Danube is a good case in point; initially the US TVA was taken as a model, before the region came under strong Soviet influence. Moscow channelled its hydroexpertise through the Council for Mutual Economic Assistance (CMEA, 1949). While this body has often been regarded as an imperialist tool in the hands of the Soviets, this image has recently been criticised. The focus on the Danube provides insight into the dynamics of the CMEA, as well as the sway of the Soviet 'model' over the Danube basin's development. The paper proceeds, first, with a section on pre-1940 planning and development, followed by the articulation of TVA-style postwar ideas about exploiting the Danube. This then in turn is contrasted with the post1948 Socialist development of the Danube with the CMEA framework. The paper concludes by reflecting upon the Danube's development, particularly in light of the US model of river development.

\section{River development in the cold war}

The cold war provided important incentives for development assistance. ${ }^{8}$ According to Arturo Escobar, the cold war was 'undoubtedly one of the single most important factors at play in the conformation of the strategy of development'. 9 After the Second World War, both the First (capitalist) and Second (Communist) provided development assistance to the Third World. The so-called Point Four speech, part of the 1949 inaugural speech of President Harry S. Truman, is often seen as the official start of Western development aid. For the East, the establishment of the CMEA in the same year can be regarded as the Communist response - in particular to the Marshall Plan. The competition between both ideologies was played out, to a large extent, in the underdeveloped parts of the world.

In the West as well as in the East, underdevelopment presented (and was perceived) both a threat as well as an opportunity. Poverty and overpopulation made countries potentially prone to socialist revolutions, and providing material and technical assistance were tools of cold-war allegiance-building. Both the First and Second World framed the 'aid rush' as an ideological struggle. A State Department official interpreted the CMEA as 'to mean that the USSR has decided to accept the challenge and, most surprisingly, has decided to wage the contest with the weapons in which we have tremendous superiority; i.e., proving assistance in the form of material aid (the Marshall Plan) and know-how (President Truman's Point Four)'. ${ }^{10}$ 
River development had a prominent place in the economic arsenal of both the Soviet Union and the United States. ${ }^{11}$ Since the end of the Second World War, the United States actively exported and promoted its own river-basin development model abroad. It, for example, based itself on the water-management experiences of the US West of the Bureau of Reclamation, responsible for the massive Hoover Dam on the Colorado River. ${ }^{12}$ But arguably the most important development 'weapon' was the Tennessee Valley Authority (TVA, 1933). As one of the emblematic projects of President Roosevelt's New Deal, the TVA sought to develop the backward US South by putting the Tennessee River to use through a system of multi-purpose dams. The TVA served (and still serves) as a multi-purpose body, pursuing various aims simultaneously; its dam-building programme contributed to power generation, flood control and navigation improvement, and was accompanied by reforestation, agricultural, and social programmes. ${ }^{13}$

Since 1933, planners from all ideological strides and corners of the world found inspiration in the TVA. In the current body of literature the TVA is often portrayed as a model that could be 'exported', 'transplanted', or even imposed. David Ekbladh recently declared it a core part of the United States' development mission abroad. ${ }^{14}$

The Soviet Union, too, enjoyed considerable experience in river development. During the 1920s and 1930s, the Soviet Union and the United States were 'caught' in a race to build the boldest and biggest dam, as Hoover Dam and Dnieprostroi Dam (1925-32) were under construction almost simultaneously. ${ }^{15}$ The main trust for this effort came from GOELRO (1920), the central plan for the electrification of the Soviet Union. GOELRO provided the 'technical and material basis' for socialism, and reorganised the country's economic structure. By 1930 its planning aims were fulfilled, even 'over-fulfilled' according to the Soviets. ${ }^{16}$ GOELRO stressed a maximum use of local fuels and resources. In the river-rich Soviet Union, this implied utilising a lot of hydropower. ${ }^{17}$ But more in general, Soviet river development was part and parcel of a wider transformation of the landscape. Reshaping the landscape with the help of new technologies should lead to 'new men': at least this was the regime's underlying rationale. ${ }^{18}$ These large-scale Soviet water projects served territorialpolitical aims at the same time. Just like other large-scale infrastructure projects, irrigation canals and hydroelectric installations sought to bring development to peripheral parts of the Soviet Union, while integrating them more strongly with the economic heartland. ${ }^{19}$

Based on these experiences, the Gidroproekt Institute was established in 1930 for designing and building hydroelectric plants. All research, development, and design work for hydroelectric plants was concentrated in a single organisation. Gidroproekt was a subdivision of the People's Ministry of Internal Affairs (Народный комиссариат внутренних дел, Narodnyy komissariat vnutrennikh del, or NKVD), the internal and secret police under Stalin. ${ }^{20}$ Its chairman was the notorious engineer Sergei Yakovlevich Zhuk. He had a hand in the design and construction of major works, including the White Sea-Baltic canal (Belomor Canal, 1931-3) and the Moscow canal, as well as several hydroelectric power stations and irrigation systems. These projects used forced labour from the GULag system. ${ }^{21}$ In addition, Gidroproekt's engineering division was staffed by a cohort of engineers that learned the ropes through the construction of the Dnieprostroi Dam. ${ }^{22}$

Gidroproekt played a very active role in post-war reconstruction, as Stalin gave new impetus to gigantic hydraulic projects after 1945. In the 1950s, the Soviet leadership pushed for the construction of huge power stations, for example at Stalingrad, 
as well as hundreds of kilometres of new canals like the Volga-Don system, as well as irrigation channels on the Dnieper River. ${ }^{23}$ Later plans were even more ambitious, far-reaching, and murderous, including the transformation of the Siberian landscape and plans for the diversion of entire rivers. Gidroproekt again aligned its agenda with the broader ideological and political aims of the Soviet leadership, as the impact on nature and respect for human life was subordinated to short-term economic gains. $^{24}$

In ways somewhat similar to the United States, the Soviet regime exported its expertise abroad - a history that remains to be written. ${ }^{25}$ Although Gidroproekt primarily developed rivers within the Soviet Union, it also employed activities abroad since the 1950s. Stalin's successor Nikita Khrushchev devoted more attention to the Third World, and pledged over US\$6 billion in the next two decades. ${ }^{26}$ Gidroproekt supervised activities on the Nile in Egypt, and later in Afghanistan and Nepal. It also assisted in the design for the vast hydropower plant at the Three Gorges on the Yangtze. $^{27}$

In the United States and elsewhere in the West, the Soviet style of river development was seen as undemocratic and totalitarian. Tireless TVA advocate and former TVA chairman David E. Lilienthal quoted a Supreme Court judge with approval: 'TVA represents an idea that can be utilised as one of the major influences to turn back the tide of Communism which today threatens to engulf Asia. ${ }^{28}$ Ekbladh argued that the TVA was part of US foreign policy to stimulate liberal development - for 'economic and social transformation guided by social science and planning'. Many thus came to view the TVA as a democratic take on planning, and an inverse version of the Soviet totalitarian model which was associated with dictatorship and coercion. ${ }^{29}$ President John F. Kennedy praised the TVA at its thirtieth anniversary, arguing that visitors from abroad gained 'an impression of vitality and growth, and the ability of people to work together in a free society'. ${ }^{30}$

As US and Soviet ideas went abroad after 1945, packaged as technical and economic assistance, they also provided the means to show off their superpower status. In some case, they found themselves competing over single rivers. One such case where river-development ideas seemed to clash was the Danube, which is described in detail in the subsequent sections.

\section{Plans for the Danube basin}

US and Soviet conceptions of river development did not find the Danube a tabula rasa. One important function of the river was navigation, and this was reflected in international regulation. Bilateral treaties dated back to 1680 , and a general regulation of freedom of navigation on international rivers was part of the acts of the Congress of Vienna of 1815. Navigational affairs fell under the competence of the European Danube Commission (EDC), in existence since 1856. After the First World War, the EDC was joined by another commission, namely the International Danube Commission (IDC). ${ }^{31}$ Navigation was the core business of both; the IDC was responsible for the Danube between Ulm (Germany) and Brăila (Romania), and the EDC for the so-called Seedonau - the part of the Danube that accommodates sea-going vessels starting at Brăila and continuing to the Black Sea. ${ }^{32}$

Since the late nineteenth century, electricity generation became a newly perceived function of rivers. The Austro-Hungarian imperial government considered building power plants in the river in 1910, but the First World War and the subsequent 
dismantling of the Habsburg Empire put a halt to such plans. ${ }^{33}$ Successor states all tried to seize their part of the river in a hydro-political struggle: the Czechoslovak delegation argued at the Paris Peace Conference for a larger share of the river, but to no avail. ${ }^{34}$ Without a hegemonic riparian state, the use of the Danube depended on international co-operation. France and Great Britain, the victorious Great Powers of the First World War, ensured their representation on the EDC while dismissing the 'losers' Austria, Hungary, and Germany - despite being riparian states. Nazi Germany agitated against this practice in 1936, and weaved a new web of bilateral conventions that effectively replaced the Commissions, making international cooperation less likely. The last meeting of the IDC, planned for the summer of 1940, was disrupted by the outbreak of war. ${ }^{35}$

Ideas from the United States left a strong imprint on initial post-war plans. US presence in the occupation zones in Austria and Germany justified a more active role in the reconstruction of the region and the utilisation of the river, at least according to the US administration. This new role built strongly upon US achievements in river-basin development, and the TVA in particular. In July 1945, proposals circulated in the State of Department, to be presented at the Potsdam Conference. One such plan pleaded for the re-establishment of the international character of the Danube. A new permanent 'authority' should safeguard this and help to improve navigation on the river. Similar internationalisation schemes were discussed for other European rivers, like the Rhine and the Elbe. ${ }^{36}$

Others made similar pleas for the Danube. Julian Huxley, the first Director of the United Nations Education and Cultural Organization (UNESCO), made a direct connection between the TVA and the future of the Danube. Inspired by a first-hand visit to the Tennessee Valley, Huxley saw potential for applying the TVA's methods elsewhere in the world, like in the Middle East and India, but also for the Danube in Europe, and promoted the idea of a 'DVA', or Danube Valley Authority. ${ }^{37}$

The same connection between territory and authority was envisioned by geographer George Kiss of the University of Michigan. Kiss was also a keen student and admirer of the TVA, and argued that the river needed some kind of 'unified control', particularly an authority to develop the Danube's resources. ${ }^{38}$ According to Kiss, the river needed an improved navigational channel, a better regulation of tributary streams by multi-purpose dams, more effective flood controls, and the means to generate electricity. Kiss also suggested a number of canals, including the Oder-Danube canal that would enable cheap bulk transport of Silesian coal. One of his more ambitious canal suggestions was that the Rhine-Main-Danube canal should become 'one of the trunk waterways of Europe'. ${ }^{39}$

International organisations, too, picked up aspects of the TVA. The wartime plans of the League of Nations similarly featured a DVA for 'the electrification and industrial development of South East Europe'. ${ }^{40}$ The United Nations Economic Commission for Europe (UNECE), initially brought into being in 1947 to buttress the post-war European economic recovery, drew similar conclusions. ${ }^{41}$ A 1948 report argued that Central and Eastern European countries located many post-war reconstruction plans in the direct vicinity of the Danube. This allowed for land improvement and reclamation, afforestation, the utilisation of electric-power resources, and the amelioration of the Danube as a waterway. UNECE's report explored several factors hampering 'optimum exploitation of the resources in the Danube Basin'. UNECE's officials thought that a closer co-ordination was needed: 'Agricultural, energy, flood-control, and navigation aspects would all need to be considered 
jointly', concluded the ECE. Afforestation should help prevent soil erosion, which in turn led to increased flooding. ${ }^{42}$ This clearly resembled a multi-purpose approach, an integral aspect of the TVA.

UNECE experts thought the Danube was particularly well suited for the generation of electricity. The river's floods were seasonally predictable, and the morphology of the Danube's tributary rivers enabled the construction of sufficiently large reservoirs. This allowed the number of dams on the main river to be limited, leaving it open for navigation. The UNECE hoped to explore further co-ordination and interconnection with energy resources in the region, including coal resources in Poland and Czechoslovakia. The Group also identified two specific projects, which both offered great potential for electricity generation. One was the so-called Iron Gates, a narrow gorge between Yugoslavia (today Serbia) and Romania. A second project was the development of the Danube Canal between Passau and Devin, near Bratislava. The first project could generate an estimated 400 to 1,000 megawatt (MW), and the second was rated at $1,900 \mathrm{MW} .^{43}$

The UNECE set up a Danube Study Group in the Electric Power Committee as a starting point. A first meeting was scheduled for September 1948, in order to make an inventory of the resources in the Danube basin and assess what projects were already under construction. Yet a few days before the meeting, the Bulgarian and Romanian government informed UNECE that it would not take part. A few days later the ECE decided to cancel the meeting altogether. ${ }^{44}$

This event was typical for the political climate in 1948. In July of that year, a meeting on Danubian navigational issues took place in Belgrade. ${ }^{45}$ The Danube meeting in Belgrade exposed a clear difference of opinion between the two superpowers, leading to a renewed division in terms of international governing bodies on the Danube. The United States preferred to continue along pre-war lines, and proposed an internationalised Danube from Ulm all the way down to the Black Sea. In addition, they demanded that the Western powers become full members of the new Danube Commission, because of their occupation zones in Germany and Austria. The Soviet Union strongly disagreed, and interpreted the US wish to be part of the European Danube Commission as an attempt to gain political and economic influence on the Balkans. The Soviet Union felt that the Danube Commission should only exist of riparian states, with them as the sole non-riparian member. $^{46}$

With the conflict unresolved, the pre-war practice of two separate organisations was renewed. The Western-oriented EDC chose Rome as its seat (not quite a riparian city!), and ceased to have concrete influence on the management of the river as such. The IDC, with its headquarters in Belgrade, would have sway over navigational issues. Soviet influence was particularly strong: according to the statues, the Secretary, the most dominant person in the Commission, was always a Soviet citizen. $^{47}$

The Soviet Union now de facto controlled the whole Danube basin from the Austria-Hungary border to the Black Sea. ${ }^{48}$ Yet the Soviet Union did not turn the new Commission into a vehicle for Soviet-led integration; it left responsibility for the improvement of Danube navigation to individual countries and bilateral arrangements. ${ }^{49}$ A similar division of labour would characterise the utilisation of Danubian resources for electricity and irrigation. The planning and execution of such development schemes took place within the framework of the CMEA's framework, which is discussed in the next section. 


\section{Soviet-style development and CMEA}

Before 1948, plans for the Danube often took the TVA as an explicit example. After 1948, the reality was a Socialist one. The path towards the industrialisation of Central and Eastern Europe was hence led and exemplified by the Soviet Union. In this process, CMEA should buttress the modernisation of Central and Eastern European countries, and further integrate the economies of the Socialist countries. This section discusses the state of the art on the CMEA, before their activities vis-à-vis the Danube are scrutinised.

How should one define the relationship between the Soviet Union and CMEA? James K. Libbey characterises the CMEA as a direct product of the cold war, in line with Soviet interests. ${ }^{50}$ Many aspects of Soviet rule in Central and Eastern Europe suggested a colonial relationship, in particular in the field of military and political relations. Therefore, the organisation is often interpreted as a Soviet imperialist tool to seize economic and political control over the region. ${ }^{51}$ But one could see CMEA in another light as well. For example, the region lacked access to Western technological assistance and support because of cold-war economic boycotts. ${ }^{52}$ The CMEA in that sense represented a forum to obtain state-of-the-art Soviet technical knowledge and material. According to Zubok, Stalin also hoped to set up a structure of production that would render Western imports obsolete. ${ }^{53}$ In that sense, CMEA was hoped to provide an alternative to Western know-how and technology.

The imperial tendencies of Moscow need some nuance as well. Several scholars have claimed that by 1948 the Soviet Union's imperial phase in Central and Eastern Europe came to an end. By then, all countries were under local Communist parties' rule. This is not to say that the Soviet Union no longer held any sway. If the US 'empire' in Western Europe was one by invitation, then Hungary was an empire by coercion, argued Borhi. Soviet influence remained large, for example, via the ruling Communist parties. ${ }^{54}$ Still, though CMEA was established in 1949, it only truly came of age in the 1960 s - thus after the 'imperial' age. ${ }^{55}$

What did this imply for CMEA and its functioning? In recent years, the nature and aim of CMEA received more scholarly attention, and historians have provided alternative interpretations for the internal dynamics of CMEA. In an instructive article, Simon Godard argues that further scrutiny of the CMEA helps to deconstruct the image of a monolithic Eastern bloc. ${ }^{56}$ Others like Sonja D. Schmid and Jiř́ Janáč argue that Moscow could not overpower its Western neighbours in technopolitical relations, especially not after $1948 .{ }^{57}$ Surely the Soviet Union kept some indirect economic control, for example via CMEA's joint-stock companies (JSCs). Memberstates bundled their interests in JSCs for key sectors like mining, shipping, and uranium ore, which bore a strong Soviet imprint. Yet this would be short-lived, as most were abolished again by the mid-1950s. ${ }^{58}$ Especially under Khrushchev, the focus reoriented on co-operation within CMEA and not blatant exploitation. ${ }^{59}$

That co-operation seemed to a large extent voluntary, and worked both ways. Soviet science and technology was very appealing and often embraced by Communists as well as non-Communists in Central and Eastern European nations, particularly with channels to the West obstructed. Their relative economic underdevelopment - with the exception of Czechoslovakia - also provided real incentives to rely on 'imported' skills and technologies. Central and Eastern European elites (both political as well as technical) found their ideas to be compatible with Soviet aims of modernisation and progress, and regarded these as apolitical and 'neutral'.60 
A reverse flow of technical expertise - from CMEA countries to the Soviet Union also sometimes took place, for example with Czechoslovakia and the German Democratic Republic. ${ }^{61}$

In addition, Socialist countries were at least able to set some limits on participation. The self-determined policy of Yugoslavia's Tito was eventually tolerated by the Soviet Union, as it gained CMEA observer status in 1956 and actively participated in several fields. Romania was able to 'maximise' its sovereignty within CMEA and successfully resisted several measures suggested by CMEA's Executive Committee. ${ }^{62}$

In sum, co-operation with Moscow did not necessarily evolve around a dominant imperial power and helpless colonies, but was within certain limits negotiated and Soviet help often gratefully accepted - if only for the lack of an alternative. In other words, insisting on a colonial relationship fails to take stock of the interests and leverage of the Central and Eastern European countries themselves, and fails to recognise CMEA as a weak tool for domination. ${ }^{63}$ It should nevertheless be clear that Moscow continued to play an influential and central role, but defining that role and assessing its degrees of control requires additional research. The case of the Danube will be a step in that direction.

\section{Developing the Danube}

How did CMEA co-ordinate and facilitate the development of the Danube? Despite a very slow start to the organisation itself, the inaugural meeting of CMEA in 1949 led to one decision regarding the river. The Romanian government - strongly supported and influenced by Stalin - proposed to build a canal linking the Danube with the Black Sea. The canal shortened the distance from Cernavodă to the Black Sea from $450 \mathrm{~km}$ to a mere $60 \mathrm{~km} .{ }^{64}$ Van Meurs suggests that Stalin himself ordered the construction of this canal, not the least because of the geo-strategic importance of the Danube-mouth region in the first decade after the Second World War. This canal would only be completed in 1984, however. ${ }^{65}$ Few other initiatives - for the river or anything else - came from CMEA in its initial years. One particular obstacle to further action was the Tito-Stalin split, which ruptured the relationship between Yugoslavia and the Soviet Union between 1948 and $1953 .{ }^{66}$ This placed all Danubian plans that involved Yugoslavia, as well as any river-wide plans, on hold, until the Yugoslav-Soviet reconciliation in 1955.

Starting in 1956, the CMEA Commission for the Exchange of Electric Energy and Utilization of the Hydraulic Resources of the Danube River provided a new institutional context. This Commission assisted CMEA countries in preparing plans for utilisation of the Danube in a variety of ways, as well as expanding the number of electricity transmission lines between their countries. The latter aspect - the eventual construction of a regional electricity network - was explicitly tied to the former: the exploitation of the Danube. As previously envisioned by the UNECE, the CMEA thought about extending the generation capacity of the Danube with other rivers and coalfields in the region. ${ }^{67}$ According to an estimate made at the first meeting of the Commission, some $25-30$ billion $\mathrm{kWh}$ of electricity could be generated per annum on the Danube from Bratislava to the Black Sea. ${ }^{68}$

The type of river development was not unlike the TVA - at least on paper. In these years, the notion of 'complex' river development became a common term to denote Soviet-style water development that involved multiple purposes. This term is very similar to the Western version of 'multi-purpose', and Central and Eastern 
European engineers sometimes named Western projects like the TVA and the development of the St Lawrence River as examples. ${ }^{69}$ According to a report from the Romanian delegation, the utilisation of Danubian hydropower should be co-ordinated with irrigation, land reclamation, inland navigation, water supply, and fishing functions. Newly planned dams would create reservoirs with a surface of approximately $6,400 \mathrm{~km}^{2}$, which in turn allowed an expansion of irrigation and water-supply systems. ${ }^{70}$ Another important aspect of its work, as noted in one CMEA document, was canalisation of the river: 'The Danube is not just a future energy supplier; in due time the river will be a waterway up to European standards. ${ }^{, 71}$ Socialist plans for the Danube can thus be characterised as multi-purpose.

The Commission established a fundamental principle during its 1956 deliberations. Projects located in a single country would be developed unilaterally by these respective countries, and projects involving more than one country would be pursued multilaterally. CMEA (and hence Soviet) experts in the technical commission would assist in co-ordination and planning, but not in the execution. ${ }^{72}$ This implied that the role of CMEA was rather limited. The May 1956 meeting also established a five-step scheme. First of all, each CMEA country would collect the necessary data (topographical, hydrological, geological) about their stretch of Danube. Subsequently, Gidroproekt in Moscow would study these data. Thirdly, the CMEA Commission would prepare a further programme for additional planning, examining, and research work. This phase was scheduled for January 1957. By then, each country made their additional research, and had more specified plans for their stretch of Danube. As a last step, Gidroproekt - supported by experts from other CMEA countries - would make final recommendations by July 1958. The CMEA Commission would discuss and approve these recommendations at the September 1958 meeting. ${ }^{73}$

Gidroproekt - the Soviet hydro-engineering institute - assumed a leading role in the process at the explicit wish of CMEA countries. The institute guided the overall progress and made final recommendations. The actual river-based projects were left to the responsible riparian states in uni- or multilateral frameworks. Prior to 1956, Czechoslovakia and Hungary had already made a scheme for the extensive exploitation of the Danube between Bratislava (Czechoslovakia) and Visegrád (Hungary). The Iron Gates had also been studied, and a hydropower station had been envisioned here at least since $1925 .^{74}$ An agreement on flow regulation at the Iron Gates was signed in 1956, from which Yugoslavia and Hungary stood to profit from land improvement and Romania from additional irrigation water. In addition, all three countries would have a new source of hydroelectric power within reach of their respective grids. A precise scheme was still unclear in 1957, as planners from both countries and Gidroproekt still discussed several options. ${ }^{75}$ Due to, again, deteriorating relations between Belgrade and Moscow, affairs concerning the Iron Gates were arranged bilaterally and outside the CMEA framework. ${ }^{76}$

Gidroproekt received the data and started its studies in the fall of 1957, leading to a number of preliminary conclusions. First, Gidroproekt considered it possible to build a series of dams in the Danube. These dams would create reservoirs that regulated water levels in the river. In total eleven hydraulic installations were mentioned in the scheme, with an installed capacity of 5.4 million $\mathrm{kW}$. In addition, navigation circumstances should be improved, argued Gidroproekt, especially on the middle stretch of the river. After building the cascade of dams, the Moscow institute advised an upgrade of the inland shipping fleet in order to be more fuel and time efficient. Lastly, Gidroproekt identified the best spots for land reclamation and irrigation in 
the Danube Valley, envisioning an expansion of irrigated land by 5 million ha. ${ }^{77}$ This multi-purpose plan included a possible link between the Danube and the Oder and Vistula basins. Further hydroelectric plants on tributary rivers would further expand the electricity-production capacity with an additional 10 million $\mathrm{kW} .^{78}$

The CMEA Commission approved Gidroproekt's report in September 1957, and asked the member states to execute their respective plans. Dams at Nagymaros (Hungary), the Iron Gates, and Wolfsthal were regarded to be priority projects - the latter being negotiated between the Austrian and Czechoslovakian governments. ${ }^{79}$ As Austria's neutrality was a precondition for regaining its independence in 1955, it was able to establish a co-operative relationship with Western Europe but also explore contacts with countries behind the Iron Curtain. In the field of electricity, it had been involved in a project to import power from Poland and Czechoslovakia since $1945 .^{80}$

A significant change occurred in 1958, as the CMEA Commission on the Danube transformed into the Permanent Commission for Electric Energy. ${ }^{81}$ After only a few years of multilateral planning under the guidance of Gidroproekt, the implementation was left to the countries themselves. No international co-ordination or authority was deemed necessary. This was also illustrated by an initiative of the UNECE. In 1958, UNECE Secretary-General Tuomioja tried to become involved in the Danube's development, and undertook steps to rejuvenate the Danube Study Group. This Group, to be composed of experts from riparian states and other interested countries, should discuss 'the multi-purpose development of the Danube, like irrigation, navigation, flood control, and electricity generation'. ${ }^{82}$ But responses were lukewarm at best. The Soviet Union, Bulgaria, and Romania never cared to respond to the invitation. Hungary, Yugoslavia, and Austria supplied the UNECE with information about their parts of the river, but expressed feelings of ambiguity for a more comprehensive consultation. The bilateral route, as was the case between the Austrians and the Czechoslovaks, seemed to be the preferred method of operation. ${ }^{83}$ This rejection took place against the backdrop of an improving relationship between CMEA and UNECE. Since 1959, firmer links were established between their respective Secretariats as both hoped to improve East-West relations. ${ }^{84}$ Rejecting co-operation with the UNECE on the Danube thus reflected the particular approach taken by Central and Eastern European states.

\section{The Danube developed?}

What eventually came of these plans for the Danube? According to a 1959 UNECE report, eight plants were operational, all of which were located on the river between the Federal Republic of Germany (FRG) and Austria, and most of them already existed before the Second World War. ${ }^{85}$ By then, the dams envisioned and discussed within the CMEA framework existed on the planning tables only. One of the priority projects was the Wolfsthal plant, located in a section where the river acts as frontier between Austria and Czechoslovakia. A provisional estimate projected a plant capacity of $200 \mathrm{MW}$. Two other schemes were jointly planned by Czechoslovakia and Hungary, respectively Nagymaros (40-50 km upstream from Budapest) and the Gabčikovo Dam between Bratislava and Nagymaros. These two dams were considered together, because of their complementary nature in terms of flood control and electricity generation. These were scheduled to be completed in 1970 and were clearly multipurpose projects; the first would generate an estimated $200 \mathrm{MW}$ and irrigate 150,000 ha of land, and the latter $700 \mathrm{MW}$ and 100,000 ha. ${ }^{86}$ This section of the 
Danube had always been hard to navigate and needed upgrading. Plans for one other priority project, the Iron Gates between Romania and Yugoslavia, also remained on the agenda. ${ }^{87}$

Overall, thus, progress was slow, and large projects like the Iron Gates, Wolfsthal, and Nagymaros took a long time to materialise, if at all. Over time, they met ever greater opposition. In addition to growing opposition to these huge projects interfering with nature, alternative forms of energy were developed as well. Nuclear energy particularly presented an alternative, which is regarded to be one of the most successful fields of co-operation within CMEA - and also took place largely in a bilateral fashion. ${ }^{88}$ This is to argue that the relative importance of hydroelectric facilities decreased, and therefore the focus on the Danube as a supplier of electricity became less pronounced.

Yugoslavia and Romania reached a consensus in 1960 on the Iron Gates project, and a bilateral treaty was signed three years later. The 1956 plans became less ambitious, as the power-plant capacity was reduced to 10.7 million MWh per year (instead of the initial 35 million MWh). Deliberations took place within the context of the Danube Commission, and not within the CMEA framework, because of the tense relations between Belgrade and Moscow. ${ }^{89}$ Only in 1964 did the building of the dam commence, to be completed in $1972 .{ }^{90}$ The construction of Iron Gate I, as it became known, was followed by Iron Gate II (opened in 1984). Today, this complex has a combined capacity of 1,026 MW for Serbia and 1,487 MW for Romania. ${ }^{91}$ The constructions at the Iron Gates also improved shipping possibilities. This part of the river had always been the most difficult to navigate, but the hydroelectric plants, equipped with the biggest locks on the Danube, helped to improve this.

Other projected schemes fared less well. The Austrian and Czechoslovak authorities abandoned the dam project at Wolfsthal in the late 1950s under fierce financial pressures and protests against its environmental impact. Czechoslovakia and Hungary signed a treaty on the Gabčikovo-Nagymaros project in 1977, and the twin dams were envisioned to improve the river's navigability and generate electricity. The Hungarian dams were planned to be in full service by 1986, and its Czechoslovak counterpart three years later. ${ }^{92}$ The dams quickly attained symbolic status in their respective countries, but in a Janus-face fashion; whereas the Czechoslovak Gabčikovo Dam became popularly seen as a positive symbol, the Nagymaros in Hungary gained a negative connotation. ${ }^{93}$ In the latter country, protests from scientists and engineers against the environmental impact of the dam were picked up by the wider population. This led the Hungarian government to suspend construction in 1981 . Hungary terminated the 1977 agreement in 1992, and today only Gabčikovo stands completed. $^{94}$

A 2011 map of the Danube shows Gabčikovo as the only dam on the stretch between the Austrian-Czech border and the Iron Gates near Belgrade. ${ }^{95}$ The CMEA's initial scheme for the Danube is largely unfulfilled.

There is little chance that it will ever be. Since 1989, significant changes took place with regard to the involvement of international organisations. First, of course, there was the demise of CMEA in 1991. At the same time, new international organisations have become involved, and new priorities came along, particularly environmental protection. The International Commission for the Protection of the Danube River was set up in 1998, to protect and promote sustainable and equitable water management in the Danube basin. With regard to navigation, the Danube Commission opened up to the West, and also welcomed international organisations like the 
UNECE and the European Union (EU) as observers. The latter has set up the EU Strategy for the Danube Region, a platform between stakeholders, riparian countries, and the European Commission, to co-ordinate policy and boost development. ${ }^{96}$ Given the current emphasis on navigation and the environment, a return to the vast and extensive dam schemes of the 1960s seems highly unlikely, and practically impossible given today's popular opinion about such projects. ${ }^{97}$

\section{Conclusions: the Danube's divided development}

This article opened by citing a US Senate report fearing Soviet competition in the field of river development. With the TVA, the United States had an appealing, powerful, and inspirational model for developing rivers. The Senate Commission nevertheless felt that Soviet-style river development was making huge progress, and came to challenge the perceived US hegemony in this field. While studying the development of the Danube, this article addressed two questions: first, how the Soviet 'alternative modernity' affected the river's development; and second, how and if the Soviet model really was different from the TVA model. An important sub-question of the latter is to what extent the Soviets were able to impose their will on the river's development, particularly within the CMEA framework.

The development of the Danube was a multi-purpose effort, as the river's utilisation focused on a number of interlocked purposes. One of these was improving navigation. This was also the oldest riverine activity for the Danube, dating back to the nineteenth century. A second major theme was developing hydropower. Several plans and suggestions appeared during the Second World War and shortly after, most of which were based on, or at least inspired by, the TVA. Yet the cold war affected the development of the Danube. Since 1948, the contours of an East-West split over the river became apparent and institutionalised, and therewith the TVA disappeared as an inspiration. Instead, Soviet models of river development entered the scene. The Gidroproekt became the main institution for planning, designing, and constructing large water-related projects in the Soviet Union in 1930. In many ways, Gidroproekt's style of river development was technically similar to that of the TVA, although within the Soviet Union (and on the Black Sea Canal) the use of unfree labour was more rule than exception - hence its direct relation with the NKVD.

The exported version of Soviet river development lacked the murderous element, as well as the breakneck pace and strong centralisation so apparent in Soviet domestic projects. This becomes even more visible when studying the case of the Danube, whose post-war development was a divided one. To be sure, such a division was not entirely new in the river's history. Between 1856 and 1920, only the lower part of the Danube fell under international control. Starting in 1920, not one, but two Danube Commissions existed. Politics seemingly always overshadowed economic interests on the river. The Great Powers of their time - Great Britain during the inter-war period, Nazi Germany before and during the Second World War, and the United States and Soviet Union after 1945 - all tried to be involved in Danubian affairs. $^{98}$

Yet the post-1945 development of the Danube was divided in two novel ways. First, there was the geographical split. Shortly after the war, it became apparent that East-West co-operation on the Danube was illusionary. The Iron Curtain ran across the river, with the Federal Republic of firmly in the West, and Austria assuming a middle position. The countries to the East fell within the Soviet sphere of influence. 
Still, the Socialist bloc was not as uniform as one might expect. The construction of a large dam on the Danube at the Romanian-Yugoslav border - the Iron Gates - was postponed due to poor relations between Yugoslavia and the Soviet Union. The CMEA, too, did not appear as a tool in the hands of the Soviet Union solely to pursue her own interests. The member countries were strongly influenced by Soviet engineering, but certainly not coerced very strongly.

This strongly related to a second type of division. The development of the Tennessee and its tributaries was in the hands of a single authority, which provided an integrated multi-purpose scheme for the river's utilization. Planners prior to 1948 similarly argued for a single co-ordinating and supervisory body. Yet in contrast to the unified TVA approach, the CMEA's plans for the Danube did not feature such an authority, contrary to what one might expect. The CMEA Standing Commission acted as a platform to discuss plans for the river, with all riparian states involved. Yet in subsequent stages the river was divided into uni- and bilateral projects. There was no central authority for the Danube's development, nor was the Soviet Union supervising the process. In fact, the CMEA Committee changed its name and function to reflect its new primary function: boasting a process of electrification and interconnection of electric power grids in the region. The CMEA no longer discussed the utilisation of the Danube from 1958 onwards. With the overarching plan in existence, it was left to the countries themselves to pursue the plan's execution, either uni- or bilaterally. This was exemplified by the lack of enthusiasm of the Socialist countries to join the UNECE's attempt to rejuvenate the Study Group for the Danube. In addition, although most of the plans were multi-purpose at least in writing, navigation was left to the already existing Danube Commission. In other words, one of the river's functions was 'outsourced' to a third body. The institutional legacy of the international river commissions for the Danube had set strong precedents for that.

What was the role of Gidroproekt after 1948? Contrary to what one might suspect, this was not a very dominant overall role, and relatively short-lived. Their involvement in the planning phase was undisputed, and their interference was to the joy of CMEA countries - at least, as the records indicate, and in line with findings by Janác and Schmidt who argue that Soviet technological knowledge certainly appealed to technical experts in CMEA countries. Hence, the overall role of the Soviet Union appears to have been limited to that of Gidroproekt, which was quite prominent, but only during the planning process. During his reign, Stalin did execute large-scale brute-force transformations of riverscapes, as the example of the Black Sea Channel shows. But in the 1960s, implementation was left to the CMEA countries themselves, and lacked the steering hand from Moscow.

Despite these differences, the planning style of Gidroproekt had some similarities with the TVA style of river development. The emphasis on multi-purpose dams and integrated planning, for example, combining electricity generation with irrigation and flood control, strikes as very similar. The Senate Committee's report equally recognised this, and characterised Soviet-style development as 'multi-purpose' and the overall use of scientific and technological means as 'not identical but basically similar to the United States'. ${ }^{99}$ Yet as shown in this article, the export of the Soviet style of river development to the Danube gave little cause for concern to the US Senate, as the comprehensive transformation of this river was divided, and never lived up to its expected potential. 


\section{Funding}

The author wishes to acknowledge support from the Netherlands Organization for Scientific Research (NWO) for their support of the project Transnationalising the TVA (dossier nr. 016.104.060).

\section{Notes}

1. United States Senate, Relationships of River and Related Water Resource and Development Programs of United States, Soviet Russia, and (Red) China: Memorandum of the Chairman to Members of the Senate Committee on Interior and Insular Affairs (Washington, 1957), 1.

2. Ibid.

3. O.A. Westad, The Global Cold War: Third World Interventions and the Making of Our Times (Cambridge, 2005), 17. Also see the more general work on Communist modernity in J.P. Arnason, 'Communism and Modernity', Daedalus, cxxix, no. 1 (2000), 61-90.

4. M. Latham, 'Modernization' in T. Porter and D. Ross (eds), The Modern Social Sciences, The Cambridge History of Science (Cambridge, 2003), 722.

5. J.A. Joyce, World of Promise: A Guide to the United Nations Decade of Development (Dobbs Ferry, NY, 1965), 43.

6. Cited in K. Gestwa, 'Technik als Kultur der Zukunft: Der Kult um die "Stalinschen Großbauten des Kommunismus", Geschichte und Gesellschaft, xxxiv (2004), 50.

7. See for examples C. Sneddon and C. Fox, 'The Cold War, the US Bureau of Reclamation, and the Technopolitics of River Basin Development, 1950-1970', Political Geography, $\mathrm{xxx}$, no. 8 (2011): 450-60; D. Ekbladh, 'Meeting the Challenge from Totalitarianism: The Tennessee Valley Authority as a Global Model for Liberal Development, 1933-1945', The International History Review, xxxii, no. 1 (2010): 47-67; R.P. Tucker, 'Containing Communism by Impounding Rivers: American Strategic Interests and the Global Spread of High Dams in the Early Cold War' in J.R. McNeill and C. R. Unger (eds), Environmental Histories of the Cold War (New York, 2010), 139-63.

8. This point by several historians, including D.C. Engerman et al., Staging Growth: Modernization, Development, and the Global Cold War (Amherst, MA, 2003); Westad, Global Cold War.

9. A. Escobar, Encountering Development: The Making and Unmaking of the Third World (Princeton, NJ, 1994), 33-4.

10. Hardy to Russel, 'Significance of the Soviet-sponsored "ECMA", 27 Jan. 1949, [Independence, Missouri,] Harry S. Truman Library, Hardy Files, box 1, folder 'Point IV' 1 of 3.

11. This is also argued in R.P. Tucker, 'Containing Communism by Impounding Rivers: American Strategic Interests and the Global Spread of High Dams in the Early Cold War' in J.R. McNeill and C.R. Unger (eds), Environmental Histories of the Cold War (New York, NY, 2010), 139-63.

12. M. Reisner, Cadillac Desert: The American West and its Disappearing Water (New York, 1986); D. Worster, Rivers of Empire: Water, Aridity, and the Growth of the American West (New York, 1985).

13. E.C. Hargrove, Prisoners of Myth: The Leadership of the Tennessee Valley Authority, 1933-1990 (Princeton, 1994), 20.

14. See, for example, amongst others, Cole et al., 'TVA'; J. Oliver, 'The Application of TVA Experience to Underdeveloped Countries' in J.R. Moore (ed), The Economic Impact of TVA (Knoxville, 1967), 25-40; H.J. Hoag, 'Transplanting the TVA? International Contributions to Postwar River Development in Tanzania', Comparative Technology Transfer and Society, iv (2006), 247-67. For David Ekbladh's pioneering work, particularly see The Great American Mission: Modernization and the Construction of an American World Order (Princeton, 2010).

15. H. Dorn, 'Hugh Lincoln Cooper and the First Détente', Technology and Culture, $\mathrm{xx}$ (1979), 322-47.

16. J. Coopersmith, The Electrification of Russia, 1880-1926 (Ithaca, NY, 1992), 50-4; V.Y. Steklov, Electrification in the U.S.S.R., D. Skvirsky (trans) (Moscow, 1960), 7-8, 30. 
17. G.A. Russo (ed), Hydroelectric Power Stations of the Volga and Kama Cascade Systems, Translation from Volzhskii Kamskii kaskady gidroelektrostantsii (Moscow, 1960), 4.

18. Gestwa, 'Technik', 44. Ideas of engineering landscapes as if they presented a clean slate, can also be found elsewhere - for example on a smaller scale in the Netherlands. Here, too, expectations about a new society ran high. See L. van der Grift, 'On New Land a New Society: Internal Colonisation in the Netherlands, 1918-1940', Contemporary European History 22 (2013), 609-626.

19. J. Obertreis, 'Infrastrukturen im Sozialismus: Das Beispiel der Bewässerungssysteme im sowjetischen Zentralasien', Saeculum, lviii (2007), 153, 179.

20. G.G. Lapin, '70 Years of Gidroproekt and Hydroelectric Power in Russia', Power Technology and Engineering, xxxiv (2000), 374; Gestwa, 'Technik', 62.

21. The construction of this canal, as with many other large-scale Soviet projects of the time, made use of forced labour. See W. Van Meurs, 'Der Donau-Schwarzmeer-Kanal, eine Großbaustelle des Kommunismus' in Ulrich Mählert et al. (eds), Jahrbuch für Historische Kommunismusforschung 2012 (Berlin, 2012), 114; P.R. Josephson, "Projects of the Century" in Soviet History: Large-Scale Technologies from Lenin to Gorbachev', Technology and Culture, xxxvi (1995), 536; Gestwa, 'Technik', 60-3. Gidroproekt's full name was named after him in his honour (S. Ya. Zhuk All-Union Scientific Research Institute for Investigations and Design 'Gidroproekt'). See '80th Anniversary of the Birth of Academician Sergei Yakovlevich Zhuk', Hydrotechnical Construction, vi (1972), 893.

22. Lapin, '70 Years', 374.

23. Gestwa, 'Technik', 42-3; Josephson, “"Projects”, 535.

24. P.R. Josephson, Resources under Regimes Technology, Environment, and the State (Cambridge, MA, 2004), 107-9.

25. The few publications on this include 'Soviet Assistance to Foreign Countries in Water Power Construction', Hydrotechnical Construction, iii (1969), 587-9; C. Katsakioris, 'Soviet Lessons for Arab Modernization: Soviet Educational Aid Towards Arab Countries After 1956', Journal of Modern European History, viii (2010), 85-106; A. Aleksandrov, N. Malyshev, and K. Smirnov, 'Major Victory of Arab and Soviet Hydrobuilders', Power Technology and Engineering, v (1971), 305-10; V.B. Vladimirov, 'Hydroproject Institute in Vietnam', Power Technology and Engineering, xxxiv (2000), 464 72; V.E. Fedosov, 'Capanda Hydroproject in Angola', Power Technology and Engineering, xxxiv (2000), 473-8; Alessandro Iandolo, 'The Rise and Fall of the "Soviet Model of Development" in West Africa, 1957-64', Cold War History, 12 (2012), 683-704.

26. Westad, Global Cold War, 67-8; Robert S. Jaster, 'Foreign Aid and Economic Development: The Shifting Soviet View', International Affairs, xlv (1969), 453.

27. Lapin, '70 Years', 376; V.D. Novozhenin and A.M. Lapshin, 'Exploitation of Water and Hydropower Resources of the Nile River', Power Technology and Engineering, xxxiv (2000), 457ff; M.I. Goldman, 'A Balance Sheet of Soviet Foreign Aid', Foreign Policy (September 1965), 350-1; A.C. Sutton, Western Technology and Soviet Economic Development 1945-1965 (Stanford, 1973), 98-9.

28. D.E. Lilienthal, TVA: Democracy on the March (New York, 1944), 211.

29. D. Ekbladh, 'Meeting the Challenge from Totalitarianism: The Tennessee Valley Authority as a Global Model for Liberal Development, 1933-1945', The International History Review, xxxii (2010), 62.

30. President John F. Kennedy, 'Remarks at Muscle Shoals, Alabama, at the 30th Anniversary Celebration of TVA', 18 May 1963, White House Audio Recordings, 1961-1963 (Muscle Shoals, Alabama, 1963), http://www.jfklibrary.org/Asset-Viewer/Archives/ JFKWHA-187-001.aspx [Accessed 25 January 2013].

31. J.L. Kunz, 'The Danube Regime and the Belgrade Conference', The American Journal of International Law, xliv (1949), 104-5; G. Thiemeyer, 'Integration der Donau-Schifffahrt als Problem der Europäischen Zeitgeschichte', Archiv für Sozialgeschichte, xlix (2009), 307; J. Chamberlain, The Regime of the International Rivers: Danube and Rhine (New York, 1923).

32. H.C. Woods, 'The Danube as an International Highway', World Today, cx (1921), 294.

33. One of the first rivers was the Rhine, where the first plants appeared in the last decade of the nineteenth century. Waterpower was obviously used earlier, for example through water wheels. J. Fitzmaurice, Damming the Danube: Gabcikovo and Post-Communist Politics in Europe (Boulder, 1996), 74. 
34. The term stems from the work of Waterbury, and involves the struggle for hegemony over the river. See his classic J. Waterbury, Hydropolitics of the Nile Valley (Syracuse, NY, 1979). Fitzmaurice, Damming, 745.

35. Kunz, 'Danube Regime', 108; Thiemeyer, 'Integration', 307.

36. 'Memorandum Regarding Policy with Respect to the Administration of the Danube River', 10 July 1945, in United States Department of State, Foreign Relations of the United States: Diplomatic Papers, The Conference of Berlin (Washington, DC, 1945), 330ff.

37. J. Huxley, TVA: Adventure in Planning (London, 1943), 135-6.

38. G. Kiss, 'TVA on the Danube?', Geographical Review, xxxvii (1947), 277-8.

39. Ibid., 288-9. A connection tying these three European rivers together would be completed in 1992.

40. Paper by J E. Wheeler, 30 Sep. 1942, Geneva, League of Nations Archives, Communications and Transit Section, Section Files (1919-1946), Transit (1919-1946), folder Communications and Transit: Post-war (1939-1945) Problems. Clavin also mentions that during their stay in at Princeton University, the League's Economic and Financial Section thought about a DVA as well. See P. Clavin, Securing the World Economy: The Reinvention of the League of Nations, 1920-1946 (Oxford, 2013), 284.

41. For more general background on the UNECE see Y. Berthelot and P. Rayment, 'The ECE: A Bridge Between East and West' in Y. Berthelot (ed), Unity and Diversity in Development Ideas: Perspectives from the UN Regional Commissions (Bloomington, 2004), 51131; G. Myrdal, 'Twenty Years of the United Nations Economic Commission for Europe', International Organization, xxii (1968), 617-28; J. Siotis, Die ECE und Gesamteuropa: Die UN-Wirtschaftskommission für Europa und ihre Bedeutung für die gesamteuropäische Zusammenarbeit (Cologne, 1969).

42. UNOG, 'Ad Hoc Committee on Industrial Development and Trade', document ID/8, 31 Jul. 1948, appendix H, 1-2 \& 5-6. This appendix contains an overview of the national development programmes in the Danube Basin.

43. Ibid., 12-13.

44. Telegrams from Kamenoff and Pauker to Myrdal, 2 Sep. 1948, U[nited] N[ations] O[rganization in] G[eneva] A[rchives], G.X 19 [Electric Power], 4.[Hydro Power], 1.[General], 6.[Hydro Power derived from Danube Basin], [folder] 4842[: Electric Power: HydroPower Derived from Danube Basin]. Letter Sevette to Asher and Warner, and telegram Sevette to Hamerschlag, Crescent, Wagner and Enezevic, both 7 Sep. 1948, UNOGA, GX 19.4.1.6. 4842.

45. Earlier the United States had hoped to arrange navigation issues related to the Rhine and Danube at the Potsdam Conference in 1945, but the Soviet Union stalled any concrete proposal. See Thiemeyer, 'Integration', 307-8.

46. Ibid., 308.

47. Ibid., 308-9.

48. Ibid., 309.

49. D.T. Cattell, 'The Politics of the Danube Commission Under Soviet Control', American Slavic and East European Review, xix (1960), 382-3.

50. J.K. Libbey, 'CoCom, Comecon, and the Economic Cold War', Russian History, xxxvii (2010), 133-52.

51. A similar remark is made in S. Plaggenborg, Experiment Moderne: der sowjetische Weg (Frankfurt am Main, 2006), 299. Valerie Bunce claims that the 'Soviets can wield the stick of imperial monopoly over all the vital economic and political resources within the empire.' See her 'The Empire Strikes Back: The Evolution of the Eastern Bloc from a Soviet Asset to a Soviet Liability', International Organization, xxxix (1985), 1.

52. Such an economic embargo was facilitated through the so-called Coordinating Committee, operating from the American embassy in Paris. See e.g. M. Mastanduno, 'The Management of Alliance Export Control Policy: American Leadership and the Politics of COCOM' in G.K. Bertsch (ed), Controlling East-West Trade and Technology Transfer: Power, Politics, and Policies (Durham, 1988), 241-79; Libbey, 'CoCom'; F.M. Cain, 'Exporting the Cold War: British Responses to the USA's Establishment of COCOM, 1947-51', Journal of Contemporary History, xxix (1994), 501-22. 
53. V.M. Zubok, A Failed Empire: The Soviet Union in The Cold War from Stalin to Gorbachev (Chapel Hill, NC, 2007), 78. Jozef van Brabant underlines the same elements in his Economic Integration in Eastern Europe: a Handbook (New York, 1989), $12 \mathrm{ff}$.

54. L. Borhi, Hungary in the Cold War, 1945-1956: Between the United States and the Soviet Union (Budapest, 2004), 200. Geir Lundestad is the inventor of the phrase 'empire by invitation'. See his 'Empire by Invitation? The United States and Western Europe, 19451952', Journal of Peace Research, xxiii (1986), 263-77.

55. M. Kaser, COMECON: Integrated Problems of the Planned Economies (London, 1965), 42-3; Naimark, 'Sovietization', 191.

56. S. Godard, 'Construire le Bloc de l'Est par l'économie?', Vingtième Siècle. Revue d'Histoire, cix (2011), 47.

57. J. Janác, European Coasts of Bohemia: Negotiating the Danube-Oder-Elbe Canal in a Troubled Twentieth Century (Amsterdam, 2012), chap. 3; S.D. Schmid, 'Nuclear Colonization?: Soviet Technopolitics in the Second World' in G. Hecht (ed), Entangled Geographies: Empire and Technopolitics in the Global Cold War (Cambridge, MA, 2011), 125, 129.

58. Brabant, Economic Integration, 18, 36.

59. Plaggenborg, Experiment Moderne, 305; M. Lavigne, International Political Economy and Socialism (Cambridge, 1991), 56.

60. Janác, European Coasts, 139; Schmid, 'Nuclear Colonalization', 130.

61. Sutton, Western Technology, 83-9.

62. S. Kansikas, 'Room to Manoeuvre? National Interest and Coalition-Building in the CMEA, 1969-74' in S. Autio-Sarasmo and K. Miklóssy (eds), Reassessing Cold War Europe (London, 2011), 198; C. Kennedy-Pipe, Russia and the World, 1917-1991 (London, 1998), 137; J.M. Montias, 'Background and Origins of the Rumanian Dispute with Comecon', Soviet Studies, xvi, no. 2 (1964), 131.

63. Several authors have claimed that CMEA was a rather weak institution. See e.g. Kansikas, 'Room to Manoeuvre?', 195; Brabant, Economic Integration, 131.

64. Van Meurs, 'Der Donau-Schwarzmeer-Kanal', 114, 116.

65. Ibid., 5. Stalin's forced industrialization 'touch' was clearly visible. Between 1949 and 1953 only seven out of sixty kilometres of canal were completed, at a cost of 60,000 deaths - which included political prisoners, soldiers, and volunteers. The construction was halted for twenty years, and again taken up under Ceauşescu and completed between 1976 and 1984. See ibid., 6-7 and D. Turnock, 'The Danube-Black Sea Canal and Its Impact on Southern Romania', GeoJournal, xii, no. 1 (1986), 69.

66. J.R. Lampe, Yugoslavia as History: Twice There Was a Country (Cambridge, 1996), 233, 245-9.

67. 'Entwurf. Berlin den 26.4.1956. Organisationsprinzipien für die Delegation der Deutschen Demokratischen Republik bei der ständigen Kommission für Elektroenergieaustausch zwischen den Ländern und für Ausnutzung der Wasserkräfte der Donau', 2-3, [Berlin-Lichterfelde], B[undesarchiv], D[eutsche] D[emokratische] R[epublik], DE 1 [Staatliche Plankommission,] I[nternationale] Z[usammenarbeit], 4101 [Ständige Kommission für Elektroenergieaustausch zwischen den Ländern und für Ausnutzung der Wasserkräfte der Donau des RGW].

68. Ibid., 4.

69. Janác, European Coasts, 171-2. A description fitting this image can also be found in N.W. Faddeev, Der Rat für Gegenseitige Wirtschaftshilfe (Berlin, 1965), 103 and Steklov, Electrification in the U.S.S.R., 115.

70. 'Technischer Bericht der Delegation der Rumänischen Volksrepublik zur Frage der komplexen Ausnutzung der Wasserkräfte der Donau', 26 April 1956, 16, and Anlage B: 'Arbeitsentwurf des Programms für die Kommission für Elektroenergieaustausch und für die komplexe Ausnutzung der Donau', 10, BDDR, DE 1, 4101.

71. Abschrift, Geheim, 4 June 1956. 'Verschlag zur Vorbereitung des Arbeitsprogramms der Kommission für den Austausch von Elektroenergie zwischen den Teilnehmerländern des $\mathrm{RgW}$ und die komplexe Ausnutzung der Wasserkräfte der Donau auf Grund der Empfelung der Beratung der Kommission, die in Moskau vom 19.-20.März 1956 stattfand', 4 June 1956, 24, BDDR, DE 1, 21753 [Vorbereitung von Tagungen und Arbeitsberichte 
der Ständigen Kommission des RGW für den Austausch von Elektroenergie und die komplexe Ausnutzung der Wasserkräfte der Donau].

72. Ibid., 5-6.

73. 'Programm und Arbeitsplan der ständigen Kommission beim Rat für gegenseitige Wirtschaftshilfe für die Erhöhung des Elektroenergieaustausches zwischen den Teilnehmerländern des Rates für gegenseitige Wirtschaftshilfe und die Ausarbeitung eines Schemas der komplexen Ausnutzung der Donau', 4 May 1956, 6-8, BDDR, DE 1, 4101.

74. Letter Charguéraud-Hartmann to Peltier, 9 June 1948, UNOGA, G.IX [Transport and Communications], 15. [Waterways], 2.4 [Internationational Rivers: Danube], folder 1.4221 Jacket 1. He makes a reference to the Hines Report of 1925, written for the League of Nations, document C.444.M.164.1925.VIII.

75. 'Information über die im Februar 1957 durchgeführte Arbeit der Kommission für den Austausch von Elektroenergie zwischen den Teilnehmerländern des RfgW und Ausnutzung der Wasserkräfte der Donau und über den Arbeitsplan der Kommission für die Zeit bis zum 15. April 1957', 4, BDDR, DE 1, 21753.

76. Kaser, COMECON, 76-7.

77. 'Beschluss zum Bericht von Hydroprojekt (UdSSR) über die Grundbestimmungen zur Erarbeitung eines Schemas für die komplexe Ausnutzung der Wasserkraftreserven der Donau', Sep. 1957, 1-2, BDDR, DE 1, 4101.

78. N.N. Antoshin, 'Cooperation Between the Member Nations of the COMECON and the Socialist Federal Republic of Yugoslavia in the Hydropower Field', Hydrotechnical Construction, viii (1974), 999-1000.

79. 'Beschluss zum Bericht von Hydroprojekt (UdSSR) über die Grundbestimmungen zur Erarbeitung eines Schemas für die komplexe Ausnutzung der Wasserkraftreserven der Donau', Sep. 1957, 2-3, BDDR, DE 1, 4101.

80. V. Lagendijk, Electrifying Europe: The Power of Europe in the Construction of Electricity Networks (Amsterdam, 2008), 169-71, 183-4. Similarly, Austria co-operated widely with its eastern neighbors, and the Soviet Union, in the field of natural gas. See P. Hogselius, Red Gas: Russia and the Origins of European Energy Dependence (New York, 2013).

81. Letter I.V. Michael to Genossen Hinkelmann, 10 Sep. 1958, BDDR, DE 1, 21753.

82. Letter Tuomioja to Austria, Czechoslovakia, Hungary, and Yugoslavia, 20 Aug. 1958, UNOG, GX 19.4.1.6., 4842.

83. Memo Sevette to Tuomoija, 'Etat d'avancement de l'organisation de la consultation sur le Danube', 24 Nov. 1958, UNOGA, Accession of Retired Records 14, number 1360: Files of Office of Executive Secretary Gunnar Myrdal, box 109, folder Energy Division 1957-60, volume I.

84. Faddeev, Der Rat, 59.

85. UNECE, 'Development of Hydro Power Stations on the Danube: Existing, Under Construction or Projected', EP/Working Paper no. 152, 23 Feb. 1959, 2.

86. Faddeev, Der Rat, 103.

87. UNECE, 'Development of Hydro Power', 4-5, 7.

88. Schmid, 'Nuclear Colonalization', 134.

89. Kaser, COMECON, 101; Janác, European Coasts, 170.

90. F.E. Ian Hamilton, Yugoslavia: Patterns of Economic Activity (London, 1968), 58.

91. See 'Tehničke karakteristike HE Đerdap 1', http://www.djerdap.rs/index.aspx? pageno $=14 \& \mathrm{mId}=177 \& \mathrm{mpId}=69$ [Accessed 30 May 2013] and 'Iron Gates Hydropower Subsidiary', http://www.hidroelectrica.ro/Details.aspx?page $=40$ [Accessed 30 May 2013].

92. Yu S. Vasil'ev and G.A. Pretro, 'Use of the Danube River and the Integrated GabcikovoNagymaros Hydro Development Project', Hydrotechnical Construction, xxiii, no. 3 (1989), 171-6; Fitzmaurice, Damming, 78-9, 81.

93. A. Vari and J. Linnerooth-Bayer, 'A Transborder Environmental Controversy on the Danube: The Gabcikovo-Nagymaros Dam System' in J. Linnerooth-Bayer, R. Löfstedt, and G. Sjöstedt (eds), Transboundary Risk Management (London, 2001), 155-82; Fitzmaurice, Damming, 86.

94. A. Schwabach, 'Diverting the Danube: The Gabcikovo-Nagymaros Dispute and International Freshwater Law', Berkeley Journal of International Law, xiv, no. 2 (2012), 296. The Slovak government, very unhappy with the Hungarian decision, went as far as the European Court of Justice in order to force Nagymaros to be built, with little success. 
95. ICOLD Hydropower \& Dams in Europe Map, 2011 Edition.

96. See 'Danube Commission', http://www.danubecommission.org/ [Accessed 31 May 2013], and 'What is the EUSDR?', http://www.danube-region.eu/pages/what-is-the-eusdr [Accessed 31 May 2013].

97. The best reflection of this is presented in P. McCully, Silenced Rivers: The Ecology and Politics of Large Dams (London, 1996).

98. This point is made in Kunz, 'Danube Regime', 107.

99. United States Senate, Relationships of River, 6. 